\title{
TINJAUAN YURIDIS TERHADAP IMPLEMENTASI PIDANA KORUPSI DALAM UPAYA MENGEMBALIKAN KERUGIAN KEUANGAN NEGARA
}

\author{
Mustaghfirin, Irwanto Efendi \\ Dosen Fakultas Hukum UNISSULA \\ mustaghfirin@unissula.co.id
}

\begin{abstract}
In Indonesia, the nature and form of corruption that has been systemic, thus making every effort to eradicate is not automatically easy to do just because of changes in democratic political constellation. Corruption is closely related to the factor of abuse of authority or influence existing on the person's position as an official who deviates from the law so that the action is detrimental to the state's economy and finances. The act of corruption is complex as a complex crime is expressed by the increasingly sophisticated modus operandi used and the shrewdness of the perpetrators in removing traces makes the disclosure of corruption criminal cases increasingly difficult to reach, thus requiring a long time and a difficult way to prove sufficiently juridically.

Considering that Corruption has been classified as extraordinary crime so that in the effort of eradication and eradication it can no longer be done normally, but in extraordinary ways (Extra Ordinary Counter Measures) as described in general explanation of Law Number: 20 Year 2001 and Law Number: 30 Year 2002 about Corruption Eradication Commission. Necessary support of all components of the nation so that law enforcement officers need not hesitate to take action against anyone who commits a criminal act of corruption because the responsibility of eradicating corruption not only lies on the shoulders of law enforcer only, but also the responsibility of all components of the nation.
\end{abstract}

Keywords: Corruption Crimes, efforts to restore losses, state finances

\begin{abstract}
Abstrak
Di Indonesia, sifat dan bentuk korupsi yang sudah sistemik, sehingga menjadikan setiap upaya pemberantasan tidak otomatis mudah dilakukan hanya karena perubahan konstalasi politik yang demokratis. Korupsi sangat erat hubungannya dengan faktor penyalahgunaan wewenang atau pengaruh yang ada pada kedudukan seseorang sebagai pejabat yang menyimpang dari ketentuan hukum sehingga tindakan tersebut merugikan perekonomian dan keuangan negara. Perbuatan korupsi sangatlah majemuk sebagai bentuk kejahatan yang rumit diungkap dengan semakin canggihnya modus operandi yang digunakan serta kelihaian pelaku dalam menghilangkan jejak membuat pengungkapan kasus-kasus tindak pidana korupsi semakin sulit dijangkau, sehingga membutuhkan waktu yang lama dan cara sulit untuk melakukan pembuktian yang memadai secara yuridis.

Mengingat Tindak Pidana Korupsi sudah digolongkan sebagai kejahatan luar biasa (Extra ordinary crime) sehingga dalam upaya penangulangan maupun pemberantasannya tidak dapat lagi dilakukan secara biasa, tetapi dengan cara-cara yang luar biasa (Extra ordinary Counter Measures) sebagaimana dijabarkan dalam penjelasan umum Undang-Undang Nomor: 20 Tahun 2001 dan Undang-Undang Nomor: 30 Tahun 2002 tentang Komisi Pemberantasan Korupsi. Diperlukan dukungan semua komponen bangsa sehingga aparat penegak hukum tidak perlu ragu-ragu untuk melakukan penindakan terhadap siapapun yang melakukan tindak pidana korupsi karena tanggung jawab pemberantasan korupsi tidak hanya terletak pada pundak penegak hukum saja, tetapi juga tanggung jawab seluruh komponen bangsa.
\end{abstract}

Kata kunci: Tindak Pidana Korupsi, upaya mengembalikan kerugian, keuangan negara. 


\section{A. PENDAHULUAN}

Indonesia merupakan Negara yang didirikan dengan kesadaran atas berkat rahmat Allah, menunjukkan adanya spirit ruhaniyah dan diniyah sebagaimana dalam alinea ketiga Pembukaan Undang-Undang Dasar $1945 .{ }^{1}$ Secara filosofis Indonesia didirikan oleh para founding father sebagai negara yang berdasarkan Pancasila dengan kerangka Bhineka Tunggal lka, yang menyatukan berbagai ragam agama, budaya, bahasa, warna kulit dalam lingkaran kehidupan keragaman dalam kesatuan.

Sampai saat ini bangsa Indonesia sedang gencarnya melaksanakan suatu misi besar yang masuk pada kategori kejahatan besar (Extra Ordinary Crimes) sehingga dapat mendukung terciptanya tujuan pembangunan Nasional yaitu menciptakan masyarakat yang adil dan makmur berdasarkan amanat pancasila dan konstitusi tertinggi UndangUndang Dasar 1945. ${ }^{2}$ Salah satu kondisi tersebut adalah penekanan supremasi hukum yang merupakan syarat mutlak bagi kelangsungan dan keberhasilan pelaksanaan pembangunan Nasional sesuai dengan cita-cita pancasila dan UUD 1945, untuk mewujudkan hal tersebut perlu ditingkatkan usaha-usaha untuk memelihara ketertiban, kedamaian dan kepastian hukum sehingga tercipta kedamaian seluruh Rakyat Indonesia. ${ }^{3}$

Perhatian terhadap masalah Korupsi sudah merupakan agenda tersendiri di dalam percaturan Internasional. Hal ini terbukti dari agenda PBB yang telah menugasi CICP yang berpusat di Wina untuk menyiapkan dan mengkaji sebuah naskah tentang "Convention Against Corruption" serta mengundang seluruh Negara anggota untuk ikut aktif dalam siding Komite persiapan untuk membahas konvensi tersebut. Indonesia termasuk salah

1 Ahmad Rofiq, Bahan diskusi persiapan penelitian pendirian rumah ibadah di Balitbang Semarang, tangal 14 Agustus 2014

2 Marwan Effendy, 2010, Pemberantasan Korupsi dan Good Governance, PT. Timpani Publishing, Jakarta, hlm. 1.

3 Romli Atmasasmita, 2004,Sekitar Masalah Korupsi Aspek nasional dan Aspek Internasional, Mandar Maju, Bandung, hlm. 54. satu Negara anggota yang ikut mendukung lahirnya konvensi tersebut dan sekaligus ikut menyampaikan konsep ketentuan tentang sistem pembuktian terbalik.Usul Indonesia tersebut mendapat sambutan yang hangat dari Negara anggota PBB sehingga patutlah kita di tanah air melaksanakan sistem tersebut sebaik-baiknya.

Akar sejarah korupsi yang sangat tua itu menjadikannya sulit diberantas, apalagi dihilangkan, sama sulitnya dengan memberantas kejahatan lainnya seperti perampokan dan pencurian, barangkali yang dapat dilakukan adalah meminimalisir dan membatasi ruang dan kesempatan terjadinya korupsi dengan langkah-langkah antisipatif (premtive atau preventif) dan penegakan hukum yang konsisten (represif dan reaktif). Di negara-negara maju yang dikenal memiliki tata pemerintahan yang baik juga bersih sering ditemuai kasus korupsi dalam skala kecil atau besar (petty and grand corruption) 4 . Kasus Enron yang tejadi di AS baru-baru ini merupakan salah satu buktinya, dengan bukti itu fenomena korupsi bukan hanya monopoli negara berkembang dan otoritarian. Indonesia adalah salah satu contoh negara berkembang yang dilanda korupsi secara sistemik. ${ }^{5}$

Sungguh ironis Negara yang kaya akan sumber-daya alam, ternyata menyimpan suatu keburukan yang sangat besar sehingga dapat merusak tatanan sosial kemasyarakatan seluruh rakyat Indonesia, sehingga akibat yang di timbulkan adalah sebagian besar masyarakat Indonesia hidup dibawah tiang gantungan kemiskinan. Sementara ditempat lain, para koruptor nyaman dan sejahtera di Negeri ini, korupsi telah membawa dampak yang buruk bagi bangsa ini karena tindakan korupsi adalah merupakan masalah yang sangat serius untuk diperangi di negeri ini karena sampai menyebabkan stabilitas dan keamanan Negara dan masyarakatnya. ${ }^{6}$

$4 \quad$ Mengenai istilah ini Klitgaard, 1998, Controlling Corruption, Los Angeles : University of California Press.

5 Kompas, 14 November 2003

6 Wiryono Prodjodikoro, 1986, Azas-azas Hukum Pidana Indonesia, Edisi kedua, Eresco, Bandung, hlm. 11. 
Pada masa kolonial belanda bentukbentuk kejahatan korupsi masih sederhana, seperti terlihat dalam rumusan KUHP, misalnya suap atau memaksa seseorang untuk memberikan sesuatu oleh pejabat atau Pegawai Negri Sipil, namun keadaan ini kemudian berubah mengikuti perkembangan Zaman sehingga salah satu isu terkuat yang dapat menumbangkan Rezim Orde Baru adalah karna meraja lelanya Korupsi, Kolusi dan Nepotisme diseluruh kalangan Masyarakat Indonesia.

Salah satu agenda reformasi pemerintah adalah penyelenggaraan pemerintah yang bersih dan terbatas dari unsur korupsi, kolusi dan Nepotisme (KKN) yaitu dalam mewujudkan Good Government kemudian di implementasikan dalam pendekatan sosio-kultural berfungsi membangun kultur masyarakat yang mengutuk tindak pidana korupsi dengan melakukan kampanye publik yang meluas keseluruh pelosok tanah air. Pemberdayaan partisipasi publik bertujuan menumbuhkan budaya anti korupsi di kalangan masyarakat mulai dari tingkat pendidikan kanak-kanak sampai kepada tingkat pendidikan tinggi, pendekatan tersebut merupakan kunci keberhasilan dalam pemberantasan korupsi yang harus dilaksanakan secara sinergis dalam satu wadah kegiatan atau aksi yang disebut Rencana Aksi Nasional (RAN) untuk pemberantasan korupsi. $^{7}$

Oleh karena itu kita harus mengetahui secara persis peta korupsi di Indonesia dan apa penyebab utamanya, seperti seorang dokter, sebelum memberi terapi (pengobatan) kepada pasiennya, harus mengetahui dahulu apa diagnosa penyakitnya. Diagnosa yang tepat membuat terapi yang dilakukan akan berhasil, tetapi jika diagnosa salah, terapi yang diberikan tidak saja gagal, malah menambah parah pasien tersebut, demikian pula dengan masa korupsi di Indonesia. ${ }^{8}$

7 Romli Atmasasmita, 2004, Sekitar Masalah Korupsi Aspek Nasional dan Aspek Internasional, Mandar Maju, Bandung, hlm. 12-13.

8 Abu fida'Abdur Rafi, 2006, Korupsi Pemerintahan Sebab
Jika kita membicarakan mengenai korupsi seakan-akan tidak ada habishabisnya tidak hanya menyangkut subyek hukum yang di Proses di pengadilan tetapi sudah diperoses di pengadilan, tetapi sudah menjadi forum diskusi tentang dampak yang timbul dan cara mengatasinya. Soedarso yang menunjuk beberapa penyebab dari korupsi selanjutnya menguraikan panjang lebar tentang latar belakang kultur ini. Antara lain sebagai berikut :

"Dalam hubungan meluasnya korupsi di Indonesia, apabila ditinjau lebih lanjut, yang perlu di selidiki tentunya bukan kekhususan orang satu-persatu, melainkan yang secara umum meliputi dirasakan dan mempengaruhi semua orang Indonesia.Dengan demikian, mungkin kita bisa menemukan sebab-sebab masyarakat kita dapat menelurka korupsi sebagai wife of life dari banyak orang, mengapa korupsi itu secara diam-diam ditolerir, bukan oleh penguasa, tetapi oleh masyarakat itu sendiri. Kalu masyarakat umum mempunyai semangat anti korupsi seperti para mahasiswa pada waktu melakukan demonstrasi anti korupsi, maka korupsi sungguh-sungguh tidak akan dikenal. ${ }^{9}$

Keberhasilan mereka dalam memberantas korupsi biasanya paralel atau berbanding lurus dengan kemajuan ekonomi dan kestabilan sosial politik masyarakatnya. Demikian juga dengan Negara-negara yang secara konsisten menjalankan prinsipprinsip tata pemerintahan yang baik (Good Governace) biasanya relatif berhasil menekan korupsi.Namun hubungan timbal balik itu tidak secara otomatis terjadi antara Negara yang menganut sistem pemerintahan demokratis, dengan keberhasilan memberantas korupsi. ${ }^{10}$

Akibat dan Reformasi, Pustaka Sinar Harapan, Jakarta, hlm. xi-xii.

9 Soedarso, B, 1969, Korupsi di Indonesia, Bhratara, Jakarta, hlm. 14.

10 Eggi Sudjana, 2008, Republik Tanpa 
Sifat dan bentuk korupsi yang sudah sistemik di Indonesia sehingga menjadikan setiap upaya pemberantasan tidak otomatis mudah dilakukan hanya karena perubahan konstalasi politik yang demokratis.Sementara itu di Cina, meskipun sistem politiknya otoritarian, tetapi dalam beberapa dekade terakhir relatif berhasil menekan wabah korupsi. Di Indonesia, korupsi sepertinya telah menjadi budaya, sehingga perlu perubahan radikal untuk memberantasnya. untuk menyikapi penomena tersebut diharapkan adanya penekanan hukum menjadi tumpuan dalam rangka merebut kembali kepercayaan masyarakat terhadap hukum, untuk itu penekanan hukum harus dilakukan secara tegas, tidak diskriminatif dan konsisten.

Berkaitan dengan masalah Tinjauan Yuridis terhadap implementasi pidana korupsi dalam upaya mengembalikan kerugian keuangan negara, Sehingga dapat diketahui apakah Undang-undang tentang korupsi yang ada selama ini telah memberikan dampak yang Positif tentang adanya upaya Pengembalian kerugian keuangan Negara yang telah merusak tatanan sosial, masyarakat dan perekonomian Negara Indonesia. Berdasarkan uraian yang dikemukakan diatas, maka penulis tertarik untuk merumuskan masalah sebagai berikut:

1. Bagaimana tinjauan yuridis terhadap implementasi pidana korupsi dalam upaya mengembalikan kerugian keuangan Negara?

2. Apa sajakah kendala dan solusinya terhadap implementasi pidana korupsi dalam upaya mengembalikan kerugian keuangan Negara?

\section{B. METODE PENELITIAN}

Penelitian ini menggunakan pendekatan yuridis empiris, yaitu suatu cara yang digunakan untuk memecahkan masalah dengan terlebih dahulu meneliti data primer di lapangan kemudian dilanjutkan dengan penelitian terhadap data-data sekunder yang

KPK Koruptor Harus Mati, JP Books, Surabaya. hlm.3. ada. ${ }^{11}$ Penelitian ini akan menghasilkan data deskriptif berupa data-data tertulisatau lisan dari obyek penelitian secara holistic (utuh), yang berkaitan dengan Tinjauan Yuridis Terhadap Implementasi Pidana Korupsi Dalam Upaya Mengembalikan Kerugian Keuangan Negara.

\section{HASIL PENELITIAN DAN PEMBAHASAN}

1. Tinjauan Yuridis Terhadap Implementasi Pidana Korupsi Dalam Upaya Mengembalikan Kerugian Keuangan Negara

Tindak pidana korupsi di Indonesia sudah meluas dalam masyarakat dalam perkembangannya terus meningkat dari tahun ketahun, baik dari jumlah kasus yang terjadi dalam jumlah kerugian keuangan negara maupun dari segi kualitas tindak pidana yang dilakukan semakin sistematis serta lingkupnya yang memasuki seluruh aspek kehidupan masyarakat sampai meningkatnya tindak pidana korupsi yang tidak terkendali akan membawa bencana tidak saja terhadap kehidupan perekonomian nasional, tetapi juga pada kehidupan berbangsa dan bernegara pada umumnya. ${ }^{12}$ Tindak pidana korupsi yang meluas dan sistematis juga merupakan pelanggaran terhadap hak-hak sosial dan hak-hak ekonomi masyarakat, begitupun dalam upaya pemberantasannya tidak lagi dapat dilakukan secara biasa, tetapi dengan cara-cara yang luar biasa.

Indonesia sebagai salah satu negara di Asia dan baru memasuki sistem kehidupan ketatanegaraan dan sistem kehidupan masyarakat baru menuju era demokratisasi, baru saja menyelesaikan satu agenda penting dalam satu perjalanan bangsa selama kurang lebih 50 tahun sejak kemerdekaannya.Agenda reformasi yang dicanangkan bangsa Indonesia pasca pemerintahan Orde Baru adalah

11 Soerjono Soekanto, 1984, Pengantar Penelitian Hukum, UI Press, Jakarta, hlm. 52.

12 Ermansjah Djaja, 2010, Meredesain Peradilan Tindak Pidana Korupsi (Implikasi Putusan Mahkamah Konstitusi Nomor 012-016-019/PPU-IV/2006, Sinar Gravika, Jakarta, hlm.129. 
memasuki suatu sistem baru dalam kehidupan berbangsa dan bernegara yang meninggalkan sistem kehidupan lama dengan ciri budaya paternalistik dan keunggulan feodalisme.Sistem baru yang diharapkan adalah sistem demokrasi dalam seluruh bidang baik bidang politik, ekonomi, hukum maupun dalam bidang sosial budaya.

Era reformasi yang dituju oleh bangsa Indonesia adalah suatu tatanan baru dalam kehidupan masyarakat, bangsa, dan negara. Untuk menciptakan kondisi tersebut bukanlah sesuatu yang mudah dan akan menghadapi tantangan yang sangat berat karena dalam abad 21 perkembangan globalisasi menuntut kesetaraan dan kesejajaran kemampuan yang paripurna serta dapat memelihara keseimbangan kehidupan didalam mengikuti perkembangan negara-negara yang telah maju. ${ }^{13}$

Berdasarkan Undang-undang Nomor 31 Tahun 1999 tentang Pemberantasan Tindak Pidana Korupsi, aturan mengenai Pengembalian Kerugian Keuangan Negara antara lain diatur dalam Pasal 32, Pasal 33 dan Pasal 34 serta Pasal 38 Undang-undang Nomor 20 Tahun 2001 tentang perubahan atas Undang-undang Nomor 31 Tahun 1999. Ketentuan-ketentuan tersebut memberikan dasar Hukum bagi negara yang di representasikan oleh Jaksa Pengacara Negara (JPN) atau pihak instansi yang di rugikan untuk melakukan gugatan perdata terhadap pelaku tindak pidana korupsi dan atau ahli warisnya. Penggunaan istrumen perdata dalam pengembalian kerugian keuangan negara mengakibatkan prosedur pengembalian aset sepenuhnya tunduk kepada ketentuan perdata yang berlaku, baik materiil maupun formal. Hubungan antara aset-aset dengan seseorang, apakah ia pelaku atau bukan pelaku tindak pidana,

13 Romli Atmasasmita, 2004, Sekitar Masalah Korupsi Aspek Nasional Dan Asperk Internasional, Mandar Maju, Bandung, hlm. 17. diatur dalam hukum kebendaan yang masuk dalam wilayah hukum sipil atau hukum perdata. ${ }^{14}$

Pengajuan gugatan dengan menerapkan instrumen Hukum Perdata sebagaimana telah diatur di dalam $\mathrm{KUH}$ Perdata dan Hukum Acara Perdata HIR/ RBg hanya berlaku sepanjang benda tersebut berada di wilayah Indonesia atau diatas kapal berbendera Indonesia, dengan demikian apabila benda tersebut berada di luar wilayah Indonesia, masalah kepemilikan dan hak kebendaan lainnya akan diatur menurut hukum perdata yang belaku di negara tersebut. Undangundang Nomor 31 Tahun 1999 juncto Undang-undang Nomor 20 Tahun 2001 tentang Pemberantasan Tindak Pidana Korupsi menganut strategi penegakan hukum represif. Pasal 4 Undang-undang Nomor 31 Tahun 1999 menegaskan hal tersebut sekaligus mengatur tentang adanya pengembalian kerugian keuangan negara yang dilakukan melalui penuntutan terhadap pelaku tindak pidana korupsi, pengembalian kerugian keuangan negara dengan menggunakan istrumen pidana menurut Undang-undang Pemberantasan Tidak Pidana Korupsi (PTPU) dilakukan melalui proses penyitaan, perampasan dan aturan Pidana denda. ${ }^{15}$

Peraturan perundang-undangan tersebut, terutama Undang-undang Nomor 20 Tahun 2001 tantang Pemberantasan Tindak Pidana Korupsi, pada proses pengembalian kerugian keuangan negara akibat pelaku tindak pidana korupsi dilakukan melalui 3 pendekatan yaitu sebagai berikut :

1. Jalur Perdata

Pendekatan melalui jalur perdata ini dapat dilihat dalam ketentuan-ketentuan pada Pasal 32 ayat (1) menetapkan bahwa

14 R. Subekti dan Tjitrosudibio, 1992, Kitab UndangUndang Hukum Perdata (Burgerlijk Wetboek dengan tambahan Undang-undang Pokok Agraria dan Undangundang Perkawinan), Pradnya Paramita, Jakarta.

15 Romli Atmasasmita, op,cit., hlm. 75. 
dalam hal penyidik menemukan dan berpendapat satu atau lebih unsur tindak pidana korupsi tidak terdapat cukup bukti, sedangkan secara nyata telah ada kerugia keuangan negara, maka penyidik segera menyerahkan berkas perkara hasil penyidikan tersebut kepada Jaksa Pengacara Negara untuk diajukan gugatan perdata atau diserahkan kepada instansi yang dirugikan untuk mengajukan gugatan. Sedangkan ayat (2) menetapkan bahwa putusan bebas dalam perkara tindak pidana korupsi tidak menghapus hak untuk menuntut kerugian terhadap keuangan negara. Pasal 33 menetapkan bahwa dalam hal tersangka meninggal dunia saat dilakukan penyidikan, sedangkan secara nyata telah ada kerugian keuangan negara, maka penyidik segera menyerahkan berkas perkara hasil penyidikan tersebut kepada Jaksa Pengacara Negara atau diserahkan kepada instansi yang dirugiakan untuk dilakukan gugatan perdata kepada ahli warisnya. Selanjutnya Pasal 38 C menetapkan apabila setelah putusan pengadilan telah memperoleh kekuatan hukum tetap (Inkrach Van Gewijde), diketahui masih terdapat harta benda milik terpidana yang diduga atau patut diduga juga berasal dari tindak pidana korupsi yang belum dikenakan perampasan untuk negara dapat melakukan gugatan perdata terhadap terpidana dan atau ahli warisnya.

2. Jalur Pidana

Disamping itu dalam hal penyitaan, diatur dalam Undangundang Nomor 8 Tahun 1981 tentang Kitab Undang-Undang Hukum Acara Pidana, yaitu dalam pasal 38 yang mengatur tentang penyitaan hanya dilakukan oleh penyidik dengan surat izin ketua Pengadilan Negeri setempat sebagaimana ditentukan dalam ayat (1), dengan pengecualian sebagaimana ditetapkan dalam ayat (2) tanpa mengurangi ketentuan ayat (1); Pasal 39 tentang benda-benda yang dapat dikenakan penyitaan; Pasal 42 tentang kewenangan penyidik untuk memerintahkan orang yang mengusai benda yang dapat disita, menyerahkan benda tersebut untuk kepentingan pemeriksaan; dan pasal 273 ayat (3) yang mengatur jika putusan pengadilan juga menetapkan bahwa barang bukti yang dirampas untuk negara, selain pengecualian sebagaimana diatur dalam pasal 46 , Jaksa mengusahakan benda tersebut kepada kantor lelang negara dalam waktu tiga bulan untuk dijual lelang, kemudian hasilnya dimasukkan ke kas Negara untuk dan atas nama Jaksa.

3. Jalur Perampasan

Dalam hal perampasan akibat pelaku tindak pidana korupsi ketentuannya diatur dalam pasal 38 ayat (5) yang menetapkan bahwa dalam hal terdakwa meninggal dunia sebelum putusan dijatuhkan dan terdapat bukti yang cukup kuat bahwa yang bersangkutan telah melakukan tindak pidana korupsi, hukum atas tuntutan penuntut umum menetapkan perampasan barang-barang yang telah disita. Pasal 38 ayat (6) yang menetapkan bahwa penetapan perampasan sebagaimana dimaksud dalam ayat (5) tidak dapat dimohonkan upaya banding, sedangkan pasal 38B ayat (2) yang menetapkan bahwa dalam hal terdakwa tidak dapat membuktikan bahwa harta benda sebagaimana dimaksud dalam ayat (1) diperoleh bukan karena tindak pidana korupsi, harta benda tersebut dianggap diperoleh juga dari tindak pidana korupsi dan hakim berwenang memutuskan seluruh atau sebagian harta benda tersebut dirampas untuk 
negara.

Di dalam upaya mengembalikan kerugian keuangan negara dengan menggunakan teori sistem Hukum yang dikembangkan oleh Friedman. Mengacu pada teori sistem hukum tersebut, terdapat tiga elemen yang membentuksistem hukum pengembalian kerugian keuangan negara akibat pelaku tindak pidana korupsi sistem hukum tersebut yaitu : elemen substansi, elemen struktur dan elemen budaya hukum dimana elemen-elemen ini memiliki karakter luas, efektif dan menyeluruh. Elemen struktur hukum ini dalam pengembalian kerugian keuangan negara yang meliputi organisasi-organisasi internasional, regional, dan lembagalembaga didalam setiap negara yang memiliki otoritas dan berkompeten dalam tugas dan tanggung jawab pengembalian kerugian keuangan negara, sedangkan elemen budaya hukum pengembalian aset meliputi aspek-aspek kesadaran serta sikap masyarakat internasional, regional dan nasional.

Wujud dari Implementasi Pidana Korupsi dalam Upaya mengembalikan kerugian keuangan negara dalam Undang-undang Nomor 31 Tahun 1999 Jo. Undang-undang Nomor 20 Tahun 2001 tentang Pemberantasan Tindak Pidana Korupsi mengenai jenis-jenis Pidana Pokok yang ada pada Pasal 10 KUHP namun jenis pidana tambahan yang ada dalam undang-undang pemberantasan tidak Pidana korupsi ini merupakan hal yang baru bagi jenis Pidana Pokok yang termuat dalam Pasal $10 \mathrm{KUHP}$ akan tetapidimuat dalam pasal 18 ayat (1) UU Nomor 31 Tahun 1999, yakni: Pertama, Perampasan barang bergerak yang berwujud atau yang tidak berwujud atau barang yang tidakbergerak yang digunakan untuk atau yang diperoleh dari tindak pidana korupsi,termasuk perusahaan milik terpidana di mana tindak pidana korupsi dilakukan, begitupula harga dari barang yang menggantikan barang-barang tersebut,
Kedua, Pembayaran uang pengganti yang jumlahnya sebanyak-banyaknya sama dengan hartabenda yang diperoleh dari tindak pidana korupsi, Ketiga, Penutupan seluruh atausebagian perusahaan untuk paling lama 1 (satu) tahun, Keempat, Pencabutan seluruhatau sebagian hakhak tertentu atau penghapusan seluruh atau sebagian keuntungantertentu yang telah atau dapat diberikan oleh pemerintah kepada terpidana.

Jadi mengenai bagaimana Tinjauan yuridis terhadap implementasi pidana korupsi dalam upaya mengembalikan kerugian keuangan negara yang terdapat Undang-undang Nomor 31 Tahun 1999 sebagaimana telah diubah dalam Undang-undang Nomor 20 Tahun 2001 tentang Pemberantasan Tidak Pidana Korupsi menurut pandangan penulis yaitu bahwa muatan pidana yang digunakan aparat penegak hukum untuk memberantas Pelaku kejahan Luar biasa (Ekstra Ordinary Crime) semakin kompleks dalam hal ketentuan pidananya sehingga dapat memudahkan upaya pengembalian kerugian keuangan negara akibat pelaku tindak pidana korupsi hal itu terbukti melalui adanya penegasan dalam berbagai pasal yang telah penulis jelaskan diatas.

2. Kendala dan Solusinya Terhadap Implementasi Pidana Korupsi Dalam Upaya Mengembalikan Kerugian Keuangan Negara.

Korupsi sangat erat hubungannya dengan faktor penyalahgunaan wewenang atau pengaruh yang ada pada kedudukan seseorang sebagai pejabat yang menyimpang dari ketentuan hukum sehingga tindakan tersebut merugikan perekonomian dan keuangan negara. Selain itu perbuatan korupsi sangatlah majemuk sebagai bentuk kejahatan yang rumit diungkap dengan semakin canggihnya modus operandi yang digunakan serta kelihaian pelaku dalam menghilangkan jejak. Keadaan ini membuat pengungkapan kasus- 
kasus tindak pidana korupsi semakin sulit dijangkau, sehingga membutuhkan waktu yang cukup lama dan cara yang cukup sulit untuk melakukan pembuktian yang memadai secara yuridis.

Kemudian disisi lain dalam hal mengungkap atau menjerat pelaku tindak pidana korupsi juga diakibatkan kesulitan jaksa penuntut umum dalam memberikan alat bukti yang dapat meyakinkan hakim, terlebih lagi dalam rangka pengungkapan perkara tindak pidana korupsi dalam proses penanganannya memerlukan konsentrasi dan kecermatan disamping pemahaman yang benar-benar terhadap Undang-Undang. ${ }^{16}$

Dalam wawancara penulis dengan salah satu Jaksa yang bertugas di Kejaksaan Negeri Kota Semarang mengatakan ada enam kendala pengungkapan kasus Tindak Pidana Korupsi yaitu : yang pertama adalah Kejahatan yang terorganisasi dalam beberapa kasus yang melibatkan pejabat atau aparat negara, kedua pelaku intelektual seringkali tidak terlibat lagsung dalam aksi kejahatan, Kendala ketiga rantai kejahatan yang panjang dapat mengakibatkan putusnya rantai alat bukti, Locus delicti bersifat lintas batas negara, ini jadi kendala keempat bahwa Locus delictiadalah tempat dan waktu terjadinya tindak pidana. Dengan terjadi melalui lintas batas negara, sehingga korupsi menjadi sulit diungkap, kendala ke lima adalah Alat dan sarana kejahatan semakin canggih, sedangkan kendala ke enam yaitu hukum seringkali tertinggal dari kejahatan, sehingga banyak tindak kejahatan yang sulit disentuh. ${ }^{17}$

Dengan pernyataan seperti yang telah di jelaskan diatas penulis berpendapat bahwa ternyata korupsi di negeri ini masih leluasa dalam mengeruk

16 Edi Yunara, 2005, Korupsi dan Pertanggungjawaban Pidana Korporasi, Citra Aditya Bakti, Bandung, hlm. 69.

17 Wawancara dengan salah satu Jaksa yang Bertuga di Kejaksaan Negeri (KAJARI) Kota Semarang keuangan negara sehingga menjadi wabah penyakit bagi seluruh Rakyat Indonesia, hal itu senada yang pernah dikatakan oleh Marwan Effendy di selasela perkuliahan beliau menyatakan bahwa " menyamakan fenomena korupsi di Indonesia seperti fenomena gunung es. "Terlihat puncaknya namun sulit diberantas. Semakin dibongkar, kasus korupsi ketahuan semakin banyak,". Pengungkapan kasus korupsi bisa dipercepat kalau sudah ditelusuri asetaset yang berkaitan dengan tersangka korupsi. "Mengikuti aliran dana tanpa diketahui tersangkanya, itu jadi paradigma baru pemberantasan korupsi," ujar dia. Pemberantasan korupsi bukan hanya milik penegak hukum, masyarakat bisa turut membantu dengan cara bekerja sama. "Cara paling efektif memberantas kejahatan adalah dengan bekerja sama, bahkan untuk kejahatan lintas negara sekalipun".

Kendala dalam pengungkapan kasus tindak pidana korupsi tidak terlepas darikarateristik tindak pidana korupsi tersebut, antara lain :

1. Pelaku tindak pidana korupsi pada umumnya tingkat pendidikan relatif tinggidan mempunyai keahlian dibidangnya, sehingga secara dini mampumenyembunyikan atau menutupi perbuatannya serta menghilangkan barangbukti yang berkaitan dengan perbuatannya sehingga mempersulit penyidikan.

2. Umumnya dilakukan oleh sekelompok orang atau beberapa orang yang salingmenikmati keuntungan dari hasil perbuatannya, sehingga saling menutup diri atau melindungi, karena takut terlibat sebagai tersangka apabila terungkap.

3. Perkara korupsi terungkap setelah berselang waktu yang relatif lama,

4. Akibatnya sulit mendapatkan alat bukti dan barang bukti yang sah menurut hukum.

5. Pelaku menggunakan sarana dan 
prasarana serta teknologi canggih yang dilakukan secara sistematis dan terencana, misalnya melalui sarana multimedia seperti komputer, internet dan lain-lain.

6. Umumnya pelaku tindak pidana korupsi adalah atasan/pimpinan (pejabat) sehingga pelaku dilindungi korp/instansi, disamping itu saksi adalah bawahan/staf sedangkan pelaku adalah atasan sehingga terkadang dalam persidangan saksi enggan memberikan kesaksian yang sebenarnya, dan mengatakan lupaatau tidak ingat lagi, bahkan mencabut keterangan yang pernah diberikan padatahap penyidikan, apakah karena sudah dipengaruhi atau mendapat sesuatu imbalan atau tekanan/ ancaman, sehingga mengaburkan alat bukti dan melemahkan pembuktian. Disamping itu, pada saat persidangan saksi berhadapan langsung dengan atasannya, sehingga menimbulkan beban psikologis bagi saksi untuk berterus terang dalam memberikan keterangan.

7. Sulitnya memperoleh alat bukti dan barang bukti yang sah menurut hukum dalam mengungkap perkara korupsi merupakan salah satu kendala pihak penyidik untuk mengajukan para pelaku korupsi ke pengadilan. Para pelaku korupsi dan saksi maupun mereka yang terlibat didalamnya sengaja menutupi sehingga pihak penyidik atau penuntut umum mengalami kesulitan untuk mendapatkan bukti-bukti dan saksi-saksi berikut data yang akurat serta konkrit sebagai dasar untuk melakukan penuntutan.

8. Tidak ada yang melaporkan sebagai saksi korban langsung. Berbeda dengan tindak pidana umum, yang dirugikan adalah person (individu) sebagai korban langsung sehingga dengan cepat segera melaporkan kasusnya kepada yang berwenang, sedangkan korban Tindak Pidana Korupsi atau pihak yang dirugikan bukan perseorangan, tetapi adalah institusi atau lembaga pemerintah/ negara.

9. Hal-hal tersebut menyebabkan tindak pidana korupsi sulit dibuktikan didalam persidangan, dan bahkan lebih sulit lagi apabila pelakunya adalah pejabat tinggi atau tokoh partai/elit politik yang mempunyai kekuasaan dan banyak massa. Disamping itu, adanya intervensi dari pejabat pemerintah/ negara yang ingin membebaskan terdakwa dari tanggung jawab pidana, baik dengan menggunakan kewenangan jabatan maupun dengan cara kekeluargaan. ${ }^{18}$

Hambatan dalam proses pembuktian ini adalah terdakwa benarbenarmelakukan perbuatan korupsi yang didakwakan karena melihat keadaan perekonomiannya yang jauh diatas penghasilan resminya, tali temali korupsi yang begitu ruwet, pintarnya terdakwa menghilangkan jejak, dan penuntut umum tidak berhasil meyakinkan hakim atas dakwaannya. ${ }^{19}$

Pelaku tindak pidana korupsi mempunyai kualitas tertentu baik kemampuan maupun kedudukan sosialnya, pelaku tindak pidana korupsi pada umumnya memiliki kualitas sebagai orang yang pintar, orang yang mempunyai wewenang dan kesempatan, modus operandi yang rumit dan dilakukan dengan teknik yang canggih, oleh karena korupsi dilakukan oleh orang pintar/berpendidikan dan mempunyai wewenang, maka perbuatan korupsi dapat ditutupi dalam jangkawaktu yang panjang sehingga sulit untuk ditaksir, terutama untuk mencari alat bukti yang diperlukan dan upaya mengembalikan uang kerugian negara, saksi-saksi dan saksi ahli sering kali kurang kooperatif, dan pelaku tindak pidana korupsi dengan

18 T. Zakaria, op, cit, hlm. 12

19 Leden Marpaung, dalam Edi Yunara, op.cit, hlm. 70 
sengaja mempersulit penyidikan. ${ }^{20}$

Hambatan lainnya yang diperoleh berdasarkan wawancara Penulis dengan salah satu Anggota Hakim ad hoc di Pengadilan Tindak Pidana Korupsi (TIPIKOR) Jawa Tengah adalah bahwa tindak pidana korupsi dilakukan secara bersama-sama, dengan kata lain korupsi tidak pernah dilakukan sendiri sehingga pihak terkait yang dijadikan saksi berupaya untuk menyelamatkan dirinya, yang mana fakta-fakta yang sebenarnya terjadi berbeda dengan yang ada dipersidangan. Dan mengenai barang bukti atau dalam hal menghadapkan tersangka, karena dalam tindak pidana korupsi pembuktian sangat sulit didapatkan. Karena hanya orangorang tertentu saja yang mengetahuinya karena hal itu sifatnya rahasia, sikap tertutup yang berasal dari orang-orang sekelilingnya menyebabkan kurang mendukung pengungkapannya. ${ }^{21}$

Penanggulangan tindak pidana korupsi selama ini sudah dilakukan dengan berbagai macam pendekatan yuridis dalam berbagai ketentuan perundang-undangan sejak tahun 1957 hingga sekarang. Namun untuk penanggulangan yang bersifat yuridis formal tersebut kurang memadai. Oleh sebab itu dalam rangka pemberantasan maupun pencegahan tindak pidana korupsi dalam upaya mengembalikan kerugian keuangan negara harus dihapuskan sebab-sebab dan kondisikondisi yang menimbulkan tindak pidana korupsi serta menghapuskan hambatanhambatan dalam penegakan supremasi hukum.

Upaya kebijakan yang serius dan komprehensif harus dilakukan untuk memberantas korupsi di Indonesia. Reformasi administrasi secara menyeluruh dalam bentuk privatisasi, deregulasi, dan desentralisasi merupakan langkah yang harus dilakukan. Untuk itu sangat perlu adanya komitmen dari seluruh masyarakat yang menganggap korupsi adalah tindakan yang amat tercela. Sehingga program penyadaran masyarakat

20 Sukarton Marmosdjono dalam Edi Yunara, op.cit, hlm. 70.

21 Wawancara dengan Anggota Majelis Hakim di Pengadilan TIPIKOR Jawa Tengah. akan bahaya korupsi sudah seharusnya dilakukan di Indonesia.

Dalam rangka Pemberantasan Tidak Pidana Korupsi (PTPK) dalam Upaya Mengembalikan kerugian keuangan Negara akibat para pelaku tindak pidana korupsi yaitu:

a. Adanya komitmen semua komponen bangsa, baik masyarakat maupun pemerintah untuk tidak melakukan sesuatu yang bisa menimbulkan tindak pidana korupsi, dan komitmen tersebut dimulai dari diri sendiri, keluarga dan lingkungan dimana kita berada.

b. Perlunya sosialisasi terhadap Undang-Undang Pemberantasan Tindak Pidana Korupsi, bahwa korupsi tidak saja melanggar hukum, tetapi juga ajaran agama sebagai mana telah di jelaskan pada bab terdahulu mengenai hadis Nabi Muahammad SAW tentang larangan kemudian bahaya laten dari perilaku korup tersebut serta nilai-nilai moral bangsa, apabila hal tersebut dilakukan akibatnya bukan hanya dirasakan oleh yang bersangkutan, tetapi juga oleh keluarga karena malu. Disamping itu perbuatan korupsi diancam dengan penjara 20 (dua puluh) tahun atau seumur hidup, bahkan dengan hukuman mati.

c. Tempat-tempat atau area yang rawan terjadinya tindak pidana korupsi tersebut ditempatkan orang yang memiliki integritas dan kepribadian yang baik dengan jaminan hidup yang memadai.

d. Terhadap mereka yang telah melaksanakan tugas dengan baik, agar diberi penghargaan berupa promosi jabatan dan kenaikan pangkat istimewa, sehingga orang lain juga dapat termotivasi untuk melakukan hal 
yang sama kemudian disisi lain agar gaji para Aparat penegak hukum dan instansi Pemerintah sebagai penyelenggara negara itu haruslah tercukupi dan menunjang sehingga tidak memungkinkan lagi bagi mereka untuk mencari penghasilan lain dengan jalan merugikan keuangan negara. Mengingat Tindak Pidana Korupsi sudah digolongkan sebagai kejahatan luar biasa (Extra ordinary crime) sehingga dalam upaya penangulangan maupun pemberantasannya tidak dapat lagi dilakukan secara biasa, tetapi dengan cara-cara yang luar biasa (Extra ordinary Counter Measures) sebagaimana dijabarkan dalam penjelasan umum Undang-Undang Nomor: 20 Tahun 2001 dan Undang-Undang Nomor: 30 Tahun 2002 tentang Komisi Pemberantasan Korupsi.

\section{PENUTUP}

\section{Kesimpulan}

Berdasarkan hasil penelitian yang telah dilakukan, penulis menarik kesimpulan bahwa:

1. Tinjauan yuridis terhadap implementasi pidana korupsi dalam upaya mengembalikan kerugian keuangan negara yang terdapat Undang-undang Nomor 31 Tahun 1999 sebagaimana telah diubah dalam Undangundang Nomor 20 Tahun 2001 tentang Pemberantasan Tidak Pidana Korupsi menurut pandangan penulis yaitu bahwa muatan pidana yang digunakan aparat penegak hukum untuk memberantas Pelaku kejahan Luar biasa (Ekstra Ordinary Crime) semakin kompleks dalam hal ketentuan pidananya sehingga dapat memudahkan upaya pengembalian kerugian keuangan negara akibat pelaku tindak pidana korupsi hal itu terbukti melalui adanya penegasan dalam berbagai pasal.

2. Korupsi sangat erat hubungannya dengan faktor penyalahgunaan wewenang atau pengaruh yang ada pada kedudukan seseorang sebagaipejabatyang menyimpang dari ketentuan hukum sehingga tindakan tersebut merugikan perekonomian dan keuangan negara. Selain itu perbuatan korupsi sangatlah majemuk sebagai bentuk kejahatan yang rumit diungkap dengan semakin canggihnya modus operandi yang digunakan serta kelihaian pelaku dalam menghilangkan jejak. Keadaan ini membuat pengungkapan kasus-kasus tindak pidana korupsi semakin sulit dijangkau, sehingga membutuhkan waktu yang cukup lama dan cara yang cukup sulit untuk melakukan pembuktian yang memadai secara yuridis.

3. Mengingat Tindak Pidana Korupsi sudah digolongkan sebagai kejahatan luar biasa (Extra ordinary crime) sehingga dalam upaya penangulangan maupun pemberantasannya tidak dapat lagi dilakukan secara biasa, tetapi dengan cara-cara yang luar biasa (Extra ordinary Counter Measures) sebagaimana dijabarkan dalam penjelasan umum Undang-Undang Nomor: 20 Tahun 2001 dan UndangUndang Nomor: 30 Tahun 2002 tentang Komisi Pemberantasan Korupsi.

\section{Saran}

1. Sekecil apapun korupsi harus segera diberantas, sebab korupsi merupakan penyebab utama menurunnya efisiensi dalam pembangunan yang sedang berjalan dalam mewujudkan 
masyarakat indonesia yang adil dan makmur berdasarkan pada Pancasila dan Undang-Undang Dasar 1945.

2. Diperlukan dukungan semua komponen bangsa sehingga aparat penegak hukum tidak perlu ragu-ragu untuk melakukan penindakan terhadap siapapun yang melakukan tindak pidana korupsi karena tanggung jawab pemberantasan korupsi tidak hanya terletak pada pundak penegak hukum saja, tetapi juga tanggung jawab seluruh komponen bangsa.

\section{DAFTAR PUSTAKA}

\section{- Buku-Buku:}

Abdurahman, 1992, Kompilasi Hukum Islam, Akademika Pressindo, Jakarta;

Ahmad Hanafi, 1993, Asas-Asas Hukum Pidana Islam, PT Bulan Bintang, Jakarta

Ahmad Rofiq, 1993, Fiqih Mawaris, Raja Grafindo Persada, Jakarta;

Al-Baihaqi, 1354 H, Assunah al_Kubra Juz 8 Bab Ma Ja-a fi at ;Ta'zir, Dar as-Sadir, Beirut;

Haliman, 1973, Hukum Pidana Syariat Islam, PT Bulan Bintang, Jakarta

Mahfud MD dkk., 1993, Peradilan Agama dan Kompilasi Hukum Islam dala Tata Hukum Indonesia, UII Press, Yogyakarta;

Marsum, 1991, Jinayat: Hukum Pidana Islam, Fakultas Hukum UII, Yogyakarta

Ronny Hanitijo Soemitro, 1994, Metodologi Penelitian Hukum dan Jurimetri, Ghalia Indonesia, Jakarta;

R. Sugandi, 1989, KUHP dan Penjelasannya, Usaha Nasional, Jakarta

Suparman Usman, 1993, Ikhtisar Hukum Waris menurut KUHP, Dar al Ulum Press 